\title{
Wudhu As a Succession of Mental Revolution For Future Generation

\author{
Dian Cita Sari
}

Universitas Islam Negeri Sultan Syarif Kasim, Riau

Email: dian.cita.sari@ univrab.ac.id

(Received: October-2017; Reviewed: October-2017; Accepted: December-2017; Published: April-2018) access under license CC BY-NC-4.0 (https://creativecommons.org/licenses/by-nc/4.0/ ).

\begin{abstract}
Ablution contains many values that can be used as supporting the education of future generations of Muslim characters. The mental revolution is a rapidly changing way of thinking to change the order of Indonesian society to be a leader in a trustful and honest future so as to bring the nation of Indonesia into a better and prosperous future. The mental revolution is aimed at ensuring that Indonesians can become a politically sovereign, economically self-sufficient and socially-socio-cultural country so that they can realize an independent, just, prosperous, civilized and civilized society. Mental revolution can utilize ablution as a process of education of character / mental revolution of future generation Indonesia in order to bring the nation of Indonesia go to happiness of life in the world and the hereafter. Through wudu, educators can make multi-use values, both physical health and psychic health as a succession of character education / mental revolution of future generations of Muslims. The location of this research at the Faculty of Medicine and Health, Abdurrab University, Riau. Type of research used is qualitative research, because the data will be presented in descriptive analysis.
\end{abstract}

Keywords: Ablution; mental revolution; self-reliance; culture; and personality.

\section{INTRODUCTION}

The Indonesian nation has a large Muslim population among the Muslim population in the world. Therefore, the Indonesian nation has a wide range of knowledge about the wisdom of wudoo that contains many values that can be a succession of character education / mental revolution of future generations of Muslims. The future generation of Indonesia is a golden generation that has the potential as a nation leader in the future that can bring the nation of Indonesia to live better than the present, which can realize the ideals of the nation in creating an advanced Indonesian society, qualified, creative, innovative, underpinned Faith, piety to God Almighty, and martyrdom.

The term mental revolution emerged first during the crowded-busy presidential election campaign period 2014-2019. President Jokowi coined the term and at the same time became the theme of his campaign that is the term Mental Revolution.

According to Raof Ahmad Bhat (2014), Now in the 21 st century we came to know that washing hands, face and other parts of the body will prevent diseases. But fourteen centuries ago when there was no microscope, Prophet (SAW), was the walking encyclopaedia of scientific discoveries \& inventions, if we may so describe him, gave us a prescription of 26 washing movements to be carried out 5 times a 
day, a total of 130 daily washing movements to grant us optimum health.

Development that only emphasizes institutional and institutional state, will not be able to deliver the people of Indonesia towards the ideals of the nation as expected or proclaimed by the founders of the nation. In order for development in Indonesia to achieve better, meaningful, and sustainable change and become a culture according to the ideals of the proclamation, namely achieve an independent, just and prosperous Indonesian society, a mental revolution is necessary.

One of the mistakes or lack of development in Indonesia lies in mental development, because the mental will bring the direction of attitudes and behavior of people or society. If the human mental of Indonesia is not good, then attitude and behavior of society will lead to bad deeds, such as demonstration, felicity, robbery, rape, murder, and so forth. Conversely, if the mental community is good, the attitudes and deeds of society will tend to better deeds, there will be no demonstrations and perfomances everywhere, rape, and murder. Community demonstrations in various fields occur because people are dissatisfied with what has happened in government, whether executive, legislative, or judicative, and the absence of gratitude of most Indonesians and state officials, resulting in state officials falling into action Violating ethics, morals, and religion.

Fights between students, and the community are also due to poor mental community, less tolerant, less grateful for the favors of Allah received, less or impatient in every facing the problems that occur in society. If the people of Indonesia are good mentally, grateful for the blessings of Allah SWT, patience, iklas, and willing to succumb, there will be no demonstration and various types of perfomance, will not be a corruption committed by state officials, executive, legislative and judiciary. To deal with the various problems that occur in the society terbut and to improve the attitudes and behavior of Indonesian society, one key is with the mental revolution.

The attempt to overcome the problems in teaching is to develop a learning journal. According to Park (2003) study journals have the potential to increase student interest and involvement with the material and encourage students to be more responsible for learning. Writing a learning journal is a reflection that various learning environments use to facilitate learning, support the development of insight, reflection, critical thinking and to know personal development.

According to Erwin (2017), For the college level, for students can be said to graduate as a scholar if the report of his research results have been tested in the trial trial thesis. To obtain this the students have an obligation to conduct research. Not just a desire to pass but by doing research students are empowered to analyze data or information systematically so as to produce valid conclusions. Systematic and legitimate keywords are in the academic world called the scientific method, while the scientific method is the concept and practice in research. Scientific methods held by students are low, with less understood what underlies the occurrence of a study beyond the desire to pass.

The mental revolution aims to make the mental changes or thinking of the Indonesian people quickly from the not good to be better, so that can be achieved the Indonesian society is an independent, cultured, and beradap or personality. The change covers all aspects of the life of Indonsia people, whether in the field of government, politics, social, culture, and education.

One of the ways to change character through mental revolution can be done through wudhu education which is khusyu, by utilizing and making examples of attitude, behavior, and speech of the language of the major Muslim scholars. Many values in wudhu can be a succession of character education / mental revolution of future generations of Muslims to become good human beings and become leaders of sidiq, amanah, tabligh, and fatonah.

According to Sudirman (2005) in the history of Islamic education, it has patterned development of an integralistic-encyclopaedic science which is affirmed by scientists such as Ibn Sina, Ibn Rushd, Ibn Khaldun who deal with the pattern of development of specific partial-specific religious scholarship on the other hand developed by scholars and experts fiqih. The separation between the two and other causes of a political-economic nature, resulted in the low quality of education and the decline of the Islamic world in general. In the three revolutions of human civilization, the green 
revolution, the industrial revolution and the information revolution, none of the Muslim scientists has been named in the gold ink sheet of the science developer, whereas the contribution of Muslim scholars is quite real. One of them is related to the value of integration of Islam and science.

For example, according to Anisa (2015), Mixing mathematics with Islamic values will form a formidable nation, scienceoriented and technologically all animated by faith and piety to God Almighty. In learning mathematics is very important to form a qualified person. If it can integrate Islam from every mathematical concept it will be easier to develop it in every learning process. Many ways can be done to teach mathematics integrated Islam to children. The most important thing is that every learning should benefit the child.

Meaning Of Mental Revolution. The globalization era is characterized by quality or quality competition, demanding all parties in various fields and development sectors to constantly improve their competence. Mulyasa (2007: 17) explains; "Competence competence puts the importance of efforts to improve the quality of education both quantitatively and qualitatively to be done continuously, so that education can be used as a vehicle in building the character of the nation".

The term revolution can mean something change in all fields. The change of an organization can be done in various ways (1) evolutionary, ie organizational change that is done when the organization is experiencing the heyday, (2) trannformation, ie organizational change when the organization's performance is very good, (3) turnaround, At a time when organizational conditions begin to decline in performance, if not changed, performance will decrease and over time the organization can experience death, and (4) revolution, ie organizational changes are done quickly and usually result in casualties and property. However, if the revolution in the mental field, will not bring casualties and property such as political revolution, social revolution, and government revolution (Muhaimin et al., 2009: 67; Supratno, 2014: 2).

The word revolution is often used in political and social terms, such as political revolution, physical revolution, industrial revolution, and social revolution. The word revolution implies a radical or rapid change that is commonly done by violence that results in the sacrifice of both life and property. The word revolution contains the connotation of a negative meaning, because every event of change with the revolution is generally violent, resulting in the loss of life and property. (Sudjatmiko, 2014: 96).

While the word mental can mean the soul, morals, or character. There are also equate the word mentality with the word personality. Personality is the overall characteristics, attitudes and values embraced by the individual to react and interact with others and the environment. Personality is generally influenced by various factors, including heredity, family relations, culture, and social class (Pangewa, 2004: 42).

Mental of words can also mean the way of thinking or mendset someone. Mental or a person's way of thinking will determine speech language, attitudes, and behavior of a person. A broad mental revolution can mean change in one's thinking from an unfavorable condition for the better. Changes in the way Indonesians think from the unhealthy to the better will bring the consequences of changing the Indonesian society to a better Indonesian society in all the life of Indonesian society, in the fields of government, politics, social, culture and education

However, a mental change in a person or society is also not easy. The mental changes of a person or society may change with full awareness or volunteering, if they are willing to evaluate themselves. Mental, attitudes, and behavior of a community person has been good or not. If not good, they are expected to have awareness to change to a better direction. These changes can be called changes internally. A person's or society's mental change can also be changed rapidly or in revolutions coming from outside parties or governments, either through coercion, policy, or legislation, or through a national movement. Such changes may be called external changes (Supratno, 2014: 4)

\section{METHOD}

The location of this research is in the Faculty of Medicine and Health, Abdurrab University, Riau. Type of research used is qualitative research, because the data will be presented in descriptive analysis. According to Moleong 
(2006: 6), qualitative research is a study aimed at understanding the phenomenon of what is experienced by research subjects such as behavior, perception, motivation, action, and others. Holistically, and by way of description in the form of words.

The approach used in this research is qualitative descriptive approach. Descriptive research is a study of observed phenomena, explaining the characteristics of phenomena or existing problems. In general, descriptive research does not use the hypothesis so that the research does not need to formulate the hypothesis. (Arikunto, 2002: 245).

This qualitative descriptive research uses a phenomenological approach. This research put forward qualitative data and in a fair field situation as it is without being manipulated. The data source in a study is the subject from which data can be obtained (Arikunto, 2002: 107). In accordance with the data obtained in this study, the researchers used data collection methods as: (1) Interview Method. Interview method is a method of collecting data with unilateral question and answer done in a systematic way and based on the purpose of the investigation (Arikunto, 2002: 146). The way that can be done is the method of collecting data by conducting question and answer with the subject of research on issues related to the problems that the author thoroughly. (2). Observation Method. Observation method is a way to get data by doing observation and recording systematically to phenomenon or phenomenon investigated and researched (Meleong, 2006:62).Observations conducted by researchers is systematic observation and deliberately used to find and dig data. (3). Documentation Method.Where in carrying out documentation techniques, researchers investigate written objects such as books, magazines, regulations, meeting minutes, diaries and so forth (Arikunto, 2002: 13).

Bogdan and Tailor mentioned that data analysis is a process that requires an attempt to identify the themes and construct hypotheses submitted by the data, as well as attempts to show that the themes and hypotheses are supported by the data (Arikunto, 2002: 183).

Because this phenomenology study includes qualitative descriptive that aims to describe a state or a phenomenon, then the analysis of data used to analyze the results of research is adjusted with existing data.

\section{RESULTS}

Ablution contains many values that can be used as a medium of mental revolution education to future generations of Indonesia. Mental changes or ways of thinking of the Indonesian people in revolution is expected that the Indonesian people will make rapid changes to a better direction in all areas, both government, politics, social, cultural, and educational, to a society that prosperous, democratic, civilized, or personable.

Technical values when in ablution include the following: (1) Wearing footwear / sandals. (2) Walking orderly to the place of ablution. (3) The queue of wudu forms the line. (4) Folding pants and sleeves. (5) Read "bismillah" before performing ablution, (6) Wudu perfectly, all parts of ablution water. (7) Using enough water, (8) Prayer after wudu. (9) When the last queue, the faucet is left in a closed position. (10) Reflecting, and straightening hair as needed. Continuous technical values carried out as a Muslim obligation turned into a habit and then gave many benefits. This positive habit pattern depends on each experience. The process of learning through this habituation makes the behavior formed relatively stable and lasting in personality. Technical values, this became the basis of the mental revolution for orderly and orderly behavior.

In essence, in addition to the requirement of valid worship, ablution is beneficial to maintain human health. There are several aspects influenced by wudu, namely:

a. Psychic. Ablution provides the peace of the soul that is able to deal with all the nerves of trouble and nervous tension. There is a qoul who says that if someone is angry, then order wudoo because ablution is able to muffle it. For the pure water of wudu will seep into the mind and heart, so that it can organize emotions well. Ablution can empty the emotions from bad influences, as well as can melesatkan positive emotions in self.

b. Physical. Medically, ablution is able to provide the health nutrients needed by humans. The fiqh scholar reveals that the benefits of wudu is an effort to maintain good health. Areas that are washed in ablution are most often in contact with 
foreign objects, including dirt. Therefore it is natural that the area that must be washed. Wudhu able to do two important things for human health, that is wudhu able to prevent the coming of disease and cure diseases.

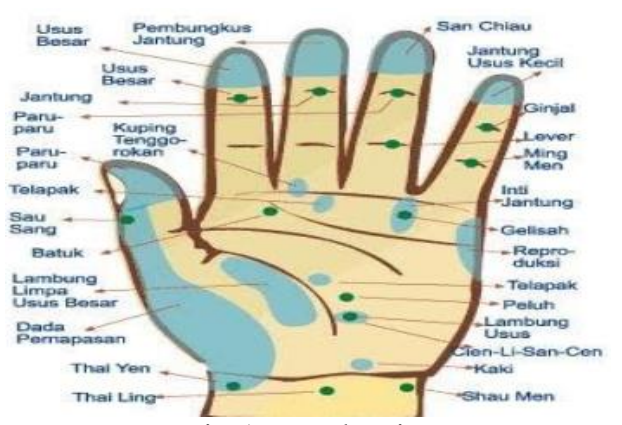

Fig.1: Hand Point

\section{CONCLUSIONS}

Based on the above description can be concluded that ablution contains many values that can be a succession of character education or mental revolution of future generations to have a better character than the present society. The mental revolution is a rapidly changing way of thinking of Indonesians in various ways, both in the fields of government, politics, social, culture, and education. The change leads to change in all fields from the not good to become better and become a culture for the whole Indonesian people. The mental revolution or the change of minds of the Indonesian people to become a culture of the bad is better aimed at the rapidly becoming the people of Indonesia to realize an independent, just, prosperous, cultured, civilized or personable state. This future generation of Indonesian mental changes can be done through the revolution of the mind using the media values in literary works.

The mental revolution of future generations must be done in order to have a good mentality and strong, have a strong faith, good morality, help others because ridho Allah regardless of social status, rank, position and religion, have the spirit of seeking knowledge, mutual respect and Tolerant of each other, always praying on time anywhere and anytime, always studying the Qur'an, parents dividing the inheritance fairly and considering the sustainability of the brotherhood, and working hard as a afterlife investment.

\section{REFERENCE}

Arikunto, S.(2002). Prosedur Penelitian: Pendekatan Praktek. Jakarta: Rineka Cipta.

Erwin S.A. (2017). Pengembangan Jurnal Belajar Untuk Meningkatkan Pemahaman Konsep dan Praktek Matakuliah Metodelogi Penelitian. Journal Educational Research and Development 1,H: 9-14

Moleong, L. J. (2006) Metodologi Penelitian Kualitatif. Bandung: Remaja Rosda Karya. 2006.

Muhaimin. (2003). Arah Baru Pengembangan Pendidikan Islam, Pemberdayaan, pengembangan dan Kurikulum Hingga Redifinisi Islamisasi Pengetahuan. Bandung: Nuansa.

Muhaimin (2009) Manajemen Pendidikan, Aplikasi dalam Penyusunan Rencana Pengembangan Sekolah/Madrasah. Jakarta: Kencana.

Park C. (2003). Engaging Students in the Learning Process: the learning journal. Journal of Geography in Higher Education 27 (2): 183- 199.

Raof A.B (2014). Unity of Health Thourgh yoga and islamic prayer "salah". Internasional Journal Academic sports scholar. 3 (10), $1-6$

Sahlan, A. (2010) Mewujudkan Budaya Religius di Sekolah. Malang: UIN-Maliki Press.

Sudirman M. Johan. (2005). Paradgma Transmisi Ilmu Pengetahuan Islam Ke Ruang Peradapan Global. Jurnal Al-Fikra 4 (1), 1-14 